\title{
Business Interests and the Development of the Modern Welfare State
}

\section{Edited by}

Dennie Oude Nijhuis

First published 2020

ISBN: 978-0-8153-7791-7 (hbk)

ISBN: 978-1-351-00239-4 (ebk)

\section{Chapter 4}

Business interests and the development of the public-private welfare mix in Switzerland, 1880-1990

Pierre Eichenberger and Matthieu Leimgruber (CC-BY-NC-ND 4.0)

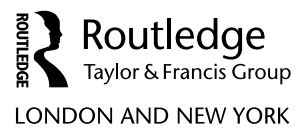




\title{
4 Business interests and the development of the public-private welfare mix in Switzerland, 1880-1990
}

\author{
Pierre Eichenberger and Matthieu Leimgruber
}

In this contribution we argue that Switzerland is a particularly interesting case to question the simplistic binary argument about whether business favored or opposed social policy development. By focusing not only on business opinions during core legislative decisions but also on both the multi-faceted as well as multilevel involvement of employers and their interest organizations in social policy development, we can thus achieve a richer understanding of the "mixed", or hybrid, nature of contemporary social security systems. ${ }^{1}$

Our approach builds on two research threads that have much contributed to improve our understanding of the making and structuring of Swiss social policy during the twentieth century. On the one hand, historical institutionalist accounts written by political scientists have underscored the role and impact of a weak central state, pervasive political decentralization and direct democracy mechanisms in the protracted and scattered development of the different components of Swiss social security (Moser, 2008; Obinger, 1998; Obinger, Armingeon, Bonoli, \& Bertozzi, 2005; Häusermann, 2010). Readers will find a concise summary of these development stages on Figure 4.1, which we replicate in the chronological structure of this chapter. If these accounts analyze key institutional features and insist on their importance for creating a propitious environment for the influence of civil society and organized interests in social policy development, historical accounts dealing with specific risks have adopted a more actorcentered approach. Focusing on accident insurance (Lengwiler, 2006), old-age provision (Leimgruber, 2008), unemployment (Tabin \& Togni, 2013), disability (Fracheboud, 2015) and family allowances (Eichenberger, 2016) - with health insurance still remaining comparatively under-studied (Lengwiler, 2009; Streckeisen, 2017) - this literature has detailed policy processes (for a useful synthesis, see Studer, 2012) as well as the implementation of risk coverage by public-private social policy providers.

As Peter Katzenstein's classical study of Swiss corporatism already argued in the 1980s, social policy long remained based on "economy [rather than] generosity" and followed "liberal values in its presumption that private organizations and individual savings [should] complement public welfare spending" (1980, pp. 508509, 540). Echoing this vision, Herbert Obinger (1998, p. 243) described Switzerland as a "liberal island within the conservative world of welfare". Yet, as we 
underscore in this chapter, business influence cannot only be measured in terms of business acquiescence or resistance to state social policy programs, but has to encompass the formation, nurturing and defense of extensive private social policy institutions, as well as the ways in which business interests succeeded in embedding themselves at the core of state social policy institutions.

Our chapter thus underscores how private, employer-led initiatives often preempted state social policy, a dimension which explains why "much of Swiss welfare policy complement[ed], rather than replace[d], preexisting private schemes, resulting in a hybrid and layered structure of social policy provision" (Bonoli \& Häusermann, 2011, p. 187). Employers consistently defended the private character of social provision as a means to limit state prerogatives in social and economic matters. They also resisted, at least in discursive terms, "the tendency to transfer individual responsibility on society, the state and [social] insurance" (Hug, 1983, p. 121). Ideological opposition against the redistributive and leveling effects of the welfare state remained a leitmotiv among Swiss employers, for example in repeated criticism against the "assistantial state", and the "socialization of revenues" that "submerged personal initiative and challenged the work ethic" (Derron, 1958 , pp. 45, 48). At the same time, employers were eager to use private social provision for labor market goals (i.e., to retain qualified workers) as a tool in industrial relations (i.e., to alleviate social conflicts) as well as financial reasons (i.e., through tax expenditures). In pursuing these objectives, employers were often joined by trade unions representing skilled workers that favored union-run welfare schemes or negotiated "paritary" solutions that were comparatively less redistributive than national social insurance solutions (Leimgruber, 2011; Trampusch, 2010).

As our chapter will also make clear, the enduring weakness of the Swiss political left, divisions among labor unions and the fact that the executive and legislative branch of the federal government maintained a consistent pro-business political majority favored business interests. To some extent, bourgeois politicians that took the lead in social policy development anticipated what was acceptable for business (on this argument, see Swenson, 2002), which made social policy not only more palatable for business, but also mitigated their potential opposition to it.

In order to underscore the changing dynamics and intensity of business involvement in social policy development, this chapter adopts a long-term, centennial perspective. After an introductory section devoted to the structure of Swiss business interest associations (BIAs) as well as their multi-faceted and multi-level involvement in social policy, we turn in a second section to the foundation of Swiss social insurance around 1900, a period that witnessed both heated debates about the "social question" as well as the emergence of BIAs. The third section of this chapter, ranging from World War I to the end of World War II, analyzes the emergence and consolidation of the public-private configurations that gave Switzerland its distinctive traits in the long term. The fourth section covers the postwar growth and crisis decades of the second half of the 20th 
century. It is devoted to issues related to the monitoring of existing public and private social provision. If our historical account stops around 1990, at the time when all major social security branches (with the exception of maternity benefits) had been introduced (see Figure 4.1 in the Appendix) we offer in the conclusion some reflections on more contemporary developments, recapitulate our main findings and point to future research topics.

\subsection{Business interest associations (BIAs) and their involvement in social provision}

In comparative perspective, Switzerland is known to have developed a distinctive form of liberal, and especially business-oriented, version of democratic corporatism, characterized by a pattern of dense formal and informal collaboration between the state and employers, with trade unions occupying a structurally dominated position in this power structure (Degen, 2012; Eichenberger \& Mach, 2011). This pattern of strong, enduring and privileged position for business interests distinguishes Switzerland from countries such as Austria, Germany or the Netherlands, where organized labor was granted more important functions in corporatist structures (Katzenstein, 1984; Trampusch \& Mach, 2011; Oude Nijhuis, 2009). The strength of BIAs which was directly related to their early foundation as well as their stability and long-term cohesiveness, contributed to make them central protagonists in social policy development.

Out of the three main BIAs still active in 2019, two were founded in the 1870s, during a period marked by economic crisis and increasing state intervention in economic and social matters. The most preeminent of these, the Swiss Federation of Trade and Industry (hereafter SHIV, or "Vorort" from the name of its steering committee), known since 2000 as economiesuisse, brought together from 1870 onwards regional chambers of commerce as well as key sector-wide associations (Humair, 2004). If the Vorort articulated a common stance for export-oriented sectors in trade negotiations, domestic-market oriented sectors convened from 1879 onwards in the Federation of Small Employers and Trades (Gewerbeverband). In addition, the Swiss Employers' Federation (Arbeitgeberverband, 1908) brought together both export-oriented industrialists (such as machine-makers and textile firms) and key domestic sectors, such as the building trades. While the Vorort dealt primarily with trade or fiscal issues, the Arbeitgeberverband articulated employers' response to growing labor militancy as well as monitored industrial relations and social policy.

While divergences of interests and tensions repeatedly surfaced between core industries, as well as between larger export-oriented firms and smaller employers focused on the domestic market we will show that these divergences were increasingly settled down within the business community. Trade unions could not count on such a cohesion, as divisions between Christian and Socialist unions (while employers never divided along religious lines), as well as between blue and whitecollar unions often split labor's positions (Oesch, 2011). These divisions came as an additional obstacle to trade unions' political effectiveness whereas employers' 
intimate connections with the bourgeois parties that dominated the Swiss political system enabled BIAs to play a significant role in policy-making, notably thanks to their systematic participation in experts' committees drafting legislative proposals (Mach et al., 2016).

BIAs' involvement in legislative development constituted only one dimension of employers' hold on social policy. Well-developed welfare institutions at the firm level led to the creation of specific interest associations of private social policy providers, notably in the pension and health domains. Commercial insurance companies were also key providers of private provision, notably in the industrial accident domain until 1918, and in retirement pensions since the 1920s. They played accordingly a vital role in lobbying and policy-making (Leimgruber, 2008). Last but not least, as we will see in the third section, BIAs founded and controlled most equalization funds (Ausgleichskassen, AKs), collecting payroll contributions and distributing benefits for key social security programs and family allowances (Eichenberger, 2016). In short, BIAs and their equalization funds formed with corporate welfare and the commercial insurance sector a multi-level system of business involvement and influence in social policy development. A concise representation of these various dimensions can be found in Table 4.1, which displays the dense array of institutions, plans and funds (that we designate as Kassenwesen, or "universe of providers") that underpinned business action (as well as contrainted labour involvement) during and beyond the twentieth century. This structure enabled business sectors to adapt private welfare to their specific needs in terms of skills and labor relations, in coherence with the decentralized organization of Swiss industrial relations, where firm and sector-level collective labor agreements (CLAs) prevailed over centralized agreements at the national level (Mach \& Oesch, 2003).

As we will see in the course of this chapter, the emergence, consolidation and cumulative nature of this multi-level structure is a major feature of Swiss BIAs' involvement in social policy development. The strength and resilience of these private institutions often contrasted with the weakness of central state administration, which reinforced subsidiarity logics and the delegation of social policy responsibilities and prerogatives to private actors.

\subsection{Uncertain beginnings? Business faces the "social question," 1890-1914}

By 1900, Switzerland figured among the richest and most industrialized countries of western Europe and faced the emergence of social risks linked to industrialization and generalized salaried work. Unemployment and work accidents as well as key issues related to compensating sick or old workers posed new challenges to the federal state, the business community and, more generally, industrial relations (Knüsel \& Zurita, 1979; Studer, 2012; Veyrassat, 2012, pp. 70-73). Early debates on the "social question" and controversies on the emerging contours of the welfare state - "the ambulance wagon of industrial capitalism" to use a catchphrase coined by historian Daniel Rodgers (1998, p. 12) - are at the center of this section. 
This period was all the more crucial that initial controversies on the organization and financing of social insurance unfolded in parallel to the structuring of BIAs.

After the Confederation had been granted a constitutional basis to legislate over social policy in 1890, a first law on sickness and accident insurance (Kranken - und Unfallversicherungsgesetzt, called Lex Forrer, after the eponymous Free Democratic Party [Freisinnige Demokratische Partei, FDP] National Councilor in charge of the project) was on the political agenda. At its core, the Lex Forrer was a political answer to industrial risks and the growing prevalence of salaried work and was intended to promote social peace, improve hygiene and increase the productivity of the labor force, as well as regulate labor market participation of children and women. Those ambitions were often anticipated at the local and cantonal levels, as well as by philanthropic initiatives and mutualism (Schumacher, 2010; Studer, 2012, pp. 928-934). This first social insurance project built on the dynamic launched by the 1877 federal law on industrial factory work (Fabrikgesetz) and the 1881 law on liability in case of work accident (Haftpflichtgesetz). It also echoed pioneering developments in neighboring Germany and Austria (Lengwiler, 2007). Both the Fabrikgesetz and Haftpflichtgesetz as well as the Lex Forrer potentially impacted the organization of industrial production and labor costs. These measures also raised key issues about the social and economic role of the state.

The Lex Forrer intended to introduce compensation for work-related accidents and health insurance covering both wage replacement and medical costs. Whereas new state plans were to implement health insurance besides already existing sickness plans, a central state agency would have been in charge of industrial accident insurance, thus crowding out casualty insurers.

Among employers, the debate on the Lex Forrer highlighted important regional, sectoral and political cleavages. As it was the case in other countries (Moses, 2015), large firms, for which industrial accidents proved financially and politically costly, welcomed social insurance as long as its costs remained low and its organization respected employers' prerogatives (Knüsel \& Zurita, 1979, p. 157). Both the Vorort and the Gewerbeverband thus insisted on a decentralized organization of accident and health insurance and the preservation of self-managed social institutions. Key BIAs secretaries and committee members also sparred over the Lex Forrer. Industrialist Eduard Sulzer-Ziegler, who had been involved as early as 1893 in the expert commission that drafted the first version of the Lex Forrer, believed that it offered a better solution than the Haftpflichtgesetz, while Vorort secretary Alfred Frey criticized the costs imposed by the new law (Wehrli, 1972, pp. 272-282). Sulzer-Ziegler's support was representative of the branch he belonged to; capital-intensive machine and metal manufacturers supported accident insurance as long as their firm-based health plans remained untouched, while labor-intensive textile or silk manufacturers - which Alfred Frey also defended - opposed payroll contributions to finance both schemes.

The Lex Forrer faced an unexpectedly protracted and uphill referendum battle. For scholars of Swiss social policy development, its May 1900 defeat underscores the institutional veto points offered by referendum politics and federalism, which 
enabled a patchwork block of dissident employers, proponents of mutualism, casualty insurers and anti-centralist conservatives to shot down the project (Obinger et al., 2005; Muheim, 2000). After the defeat of the law, the Federal Council immediately set out to prepare a new, watered-down version. Assuaging proponents of mutualism and downplaying centralization, this new proposal was accepted by Parliament in 1911 and cleared the referendum hurdle in 1912.

Accident insurance was limited to dangerous industrial occupations and implemented from 1918 onwards by the Swiss Accident Insurance Institute (SUVA). This tripartite institution supervised by federal, business and trade union representatives monitored employers' contributions to the system and organized the payment of benefits. While the SUVA monopoly expelled casualty insurers from this market, its tripartite structure, which has remained unique in the management of Swiss social policy, guaranteed business and labour oversight (Lengwiler, 2006). The new law also introduced, from 1914 onwards, subsidies to existing sickness plans, which covered around 20 percent of the overall population by 1920 . The defense of firm-based solutions anticipated the much more important role this issue would play during the interwar period in the domain of old-age provision. Health insurance expanded chiefly at the regional level - where cantonal governments could declare mandatory affiliation to health funds for certain population categories - but the decentralized nature of health insurance was maintained. In 1900, for example, firm-based plans covered around one fifth of all wage-workers affiliated to sickness funds (Fleischmann, 2016). The 1911 law was thus more attuned to employers' preferences. However, the business community was again divided on the issue: out of the 44 chambers of commerce and trade associations affiliated to the Vorort, 22 had opposed the 1911 project (among them textile and chemical firms insurance companies and chambers of commerce of the three main cities), while 11 had been in favor (among them the machine industry) and 11 remained uncommitted (Richard \& Georg, 1911, pp. 46-47).

The bruising process leading to the 1912 vote was a defining moment in social policy development. It set a pattern in which the fight for social insurance proved to be an uphill battle against the "constituted field of interests" (Rodgers, 1998, pp. 259-260). Emboldened by referendum campaigns, non-state providers - non-profit mutualism, firm-based solutions as wells as commercial insurers - proved resilient and enduring. The integration of existing providers through subsidization and delegation of state tasks became crucial. Significantly, the Federal Social Insurance Office established in 1913 did little to increase administrative capacity in social policy development as its main task focused on the supervision of subsidies to health funds. During these early debates, BIAs were still relatively loosely organized - a situation that would change in the next periods - and their internal divisions thus often played out in the open. 


\subsection{The roots of the public-private welfare mix, 1914-1948}

The "Age of Catastrophe" (Hobsbawm, 2012) encompassing the two world wars as well as the economic crises of the interwar decades constituted a second crucial step for the development of the Swiss welfare state (for more on the war and welfare nexus, see Leimgruber, 2018). It is also during this period that business prominence in the hybrid public-private welfare mix was consolidated. This period can be divided in three main phases. During the first phase, running from 1914 to 1931, key labor market issues, including unemployment compensation, as well as old-age provision were on the top of the agenda. As in other European countries, the transition from wartime emergency to postwar stabilization proved difficult (Maier, 1988). As the Great Depression (1931-1938) witnessed, paradoxically, a stagnation of Swiss social policy development, the 1930s will be only cursorily analyzed here. By contrast, major social policy breakthroughs characterized the "war decade", 1938-1948. We thus identify a second phase focused on the introduction in 1940 of income compensation for mobilized soldiers, a key family policy, and, a third phase, centered on the 1944-1948 shaping of oldage pensions, the cornerstone of the postwar welfare state.

Business involvement in the shaping of unemployment insurance, income compensation and old-age provision was important. As we will see below, business action resulted in the consolidation of private social provision (old age), in the weakening of trade unions schemes (unemployment) and the embedding of business interests in the core functioning of social insurance (income compensation and old age). These outcomes were assuredly facilitated by the fact that neutral Switzerland remained outside of military conflagrations and that bourgeois parties always held a large political majority - and this despite the 1919 introduction of proportional representation and the 1943 entry of the Socialist Party in the Federal Council. Both factors contributed to insulate BIAs from the disruptions that many of their European counterparts experienced as well as guaranteed them a privileged access to policy making.

\subsubsection{Unemployment insurance and old-age pensions in the aftermath of World War I}

Although Switzerland remained neutral during World War I, the social, economic and political impact of the war was substantial. Monetary inflation, bottlenecks in food supply as well as the general lack of preparation of the federal state disrupted social conditions and fueled political radicalization. These escalating social and political tensions - which peaked in the only General Strike (Landesstreik) in Swiss history in November 1918 - set the difficult stage in which employers had to face industrial relations and social policy (Eichenberger, 2018).

If Switzerland followed the international introduction of the 8-hour day, employer associations struggled to implement it in an orderly way. The war aftermath also witnessed the negotiation of limited collective labor agreements (CLAs) in branches such as the building trades, while firm-level 
negotiation was privileged in sectors like the machine and metallurgy sector (Degen, 2012). Employers remained, however, divided on major political options. While most industrial employers gave qualified support to state intervention - most of them thought some level of state intervention had become inevitable after the General Strike - fiscal conservatives from western Switzerland, as well as textile and chemical industrialists opposed any public intervention in labor relations (Schmid, 1983, pp. 183-202).

World War I and its aftermath was a defining period for unemployment provision. During the war itself, emergency subsidies had been granted to existing unemployment schemes managed by trade unions. Employers agreed, though reluctantly, to these subsidies as they alleviated social tensions and stabilized industrial relations. During the 1921-1922 economic crisis, unemployment continued to be a pressing issue. This led to the drafting of a federal law on unemployment insurance, whose aim was to anchor a Ghent style subsidy system for existing unemployment schemes, at the time dominated by trade unions. Crucial for employers in this context was to control how trade unions could use state subsidies and to limit employers' financial participation. BIAs debated whether all unemployment schemes should be required to include employers' representatives but discarded this option as it would have required employers to contribute financially to these schemes. Employers insisted instead that higher subsidies should be granted to new types of unemployment coverage: paritary schemes jointly managed by trade unions and employers and schemes set up by local authorities, both of which would then compete against trade union schemes. Weakened by the war and the economic crisis, trade unions schemes remained dominant in the distribution of benefits, but their financial autonomy was restrained. The 1924 law on unemployment insurance also encouraged subsidized public works that kept enterprises at work and enabled firms to file for "partial unemployment" during periods of low economic activity in order to retain skilled workers with state help. But besides limited support to existing schemes, the 1924 reform did not introduce generalized unemployment insurance coverage, which remained below one-third of the workforce until the 1970s (Tabin \& Togni, 2013).

Unemployment insurance, however, remained a sideshow in comparison to the stakes surrounding the interwar attempt to introduce federal old-age pensions. These efforts took place on two very different levels. Heated political controversies surrounded the organizational structure and financing of old age and survivors' pensions (Alters- und Hinterlassenenversicherung, AHV). It took 6 years, from 1919 to 1925, to introduce a constitutional basis for the AHV and another 4 years to draft a law project. Two years later, in December 1931, the law failed to clear the referendum hurdle.

But before analyzing the controversies on the 1929 AHV bill we have to focus on a second and more submerged phenomenon, namely the emergence of private old-age provision. By the end of the war, corporate welfare institutions, and in particular pension plans, were established at a breakneck pace. This surge was related to the introduction of emergency taxes targeting war profits but at the same time offering rebates if employers set up "welfare institutions" so as 
to alleviate deteriorating social conditions (see Figure 4.2, and for an analysis: Leimgruber, 2008). Employers were keen to use this opportunity to reduce their tax bills, and all the more so that corporate welfare was not only fiscally attractive but also contributed to pacify industrial relations in the aftermath of the 1918 General Strike. This situation also jumpstarted a new market for life insurance companies offering group contracts to employers unable or unwilling to set up their own pension plans. The defense of voluntary pension solutions led to the foundation in 1922 of the Association of Private Old Age and Disability Plans (Schweizerischer Verband der Unterstützungskassen und Stiftungen für Alter und Invalidität, SVUSAI). The explicit aim of this reunion of leading pension plans and life insurers was to ensure the autonomy of occupational provision vis-à-vis the future AHV as well as fight any attempt to exclude private providers. This point was particularly dear to insurers who, as we have seen in the precedent section, had just been crowded out of the accident insurance market by the SUVA.

However modest in its scope, the 1929 AHV project was controversial within business circles. Financed through payroll levies topped by the returns of alcohol and tobacco taxes, the AHV would have been implemented by cantonal funds and offered universal basic flat-rate pensions complemented by means-tested benefits. Existing pension plans would have been able to continue their operations if they offered superior benefits. Employers fought to limit costs and to protect their pension plans, with marked divisions between sectors. For example, machines and metal industrialists with well-developed pension plans were again more supportive of the federal project than textile or chemical manufacturers. That said, the impulsion for the law was clearly in the political arena and employers remained on the sidelines, their BIAs being wary to see their ranks split again on the issue of social insurance (Leimgruber, 2008, pp. 90-102).

Despite their divisions, business representatives could not openly oppose a project that had been drafted by Edmund Schulthess, a bourgeois FDP Federal Councilor who had long worked for BBC (now ABB), a leading electro-engineering firm. Accordingly, when the Arbeitgeberverband held in November 1931 a general assembly on the AHV bill, two-thirds of delegates voted in favor of its adoption. Carl Sulzer-Schmid, a seasoned member of the parliament and the president of the machine and metallurgy trade association (VSM) argued that business critics had been heard. He urged his peers to support a compromise that was "in the interests of the country and of employers" (Arbeitgeberverband, 1931a, p. 151). Arbeitgeberverband secretary Otto Steinmann also argued that the law was a "lesser evil" as it would demonstrate employers' goodwill and would enable them to ward off unwelcome developments in other social policy domains, such as a health insurance (Arbeitgeberverband, 1931b, p. 93). Opponents of the law - and among them Carl Sulzer-Schmid's relative Oskar Sulzer, also a machinemaking industrialist - voiced their concern against state intervention and the negative increase in labor costs. Despite remaining in the minority, dissent against the AHV was leveraged by the pension lobby. As we have underscored above, the protracted politics of the AHV had left time for corporate plans to consolidate their positions. In 1929, the pension lobby (SVUSAI) 
thus warned the Federal Council that any AHV law that would not guarantee opting out solutions for firm-based plans would face relentless opposition. This position originated from the composition of the pension lobby, which was at that time dominated by pension plans from the Basel textile and chemical sector, where employers were facing off a local proposal to set up a cantonal AHV system. This undoubtedly contributed to sharpen their opposition to any similar federal scheme. In the end, the fate of the AHV law was also linked to its unfortunate timing with the ongoing deterioration of the economic situation following the 1929 crash. By late 1931, unemployment was on the rise and economic uncertainty put wind in the sails of the patchwork referendum coalition that successfully shot down the AHV in December of this year.

After the defeat of the AHV, social policy development stalled for good. Despite the economic crisis, no significant advance in social policy was undertaken at the federal level. Increased subsidies flowed into unemployment plans, and cantons expanded health insurance for fragilized population groups, such as children and the poor, but no change was made to the overall decentralized structure of both programs (Tabin \& Togni, 2013). Existing pension plans offered meager benefits and were used by some employers to ease lay outs. However, they did not face competition from a new AHV, a situation which might have crippled their development during the recession. The autonomy of non-state providers was thus preserved, and this had wider ranging consequences than in the domain of health insurance: occupational pension plans not only garnered important reserves (reaching already 26 percent of GDP in 1937) and represented a burgeoning market for life insurers, but also played an increasing role to retain skilled workers (Leimgruber, 2008). The development of firm-based corporate benefits also contributed to employers' preference to keep organized labor at arm's length instead of developing CLAs. With the significant exception of the often overrated 1937 Labor Peace Agreement in the machine and metal industry, CLAs remained sparse before the late 1940s. Moreover, the left and labor attempts to increase state intervention to fight the economic crisis, for example, with their 1935 "Labor Plan Initiative" (Plan der Arbeit) failed to overcome the direct democracy blockade (Müller, 2010). Last but not least, the 1930s witnessed important changes in the internal organization of BIAs. The experience of the divisions that had marred policy and social insurance debates in the 1920s and in 1931 led to a tightening of internal structures. Both the Vorort and the Arbeitgeberverband introduced new rules that centralized decision-making and reinforced their governing boards. From this point onward, internal debates and divisions were kept behind closed doors (Eichenberger, 2016). These combined factors would play a decisive role in strengthening employers' hand during World War II and its aftermath.

\subsubsection{The EO breakthrough and the wartime surge of corporate welfare, 1938-1944}

Swiss historiography has highlighted that the "war decade", which ran from the early planning for the war economy in 1938 to the 1948 
postwar settlement at both the international and domestic levels, as a crucial period to understand the trajectory of the Swiss welfare state and business involvement in social policy development (for the definition of the period, see Jost, 1999; Leimgruber, 2008, pp. 116-186; 2018). Between 1938 and 1940, BIAs were at the forefront of a major social policy innovation, namely income compensation for militia soldiers (Erwerbersatzordnung, EO). Right after, from 1941 onwards, a second surge of corporate welfare schemes both expanded and strengthened the reach of private social provision (see Figure 4.2). Those combined developments gave employers much leverage during the foundation of the AHV. During World War II, employers' willingness to support social benefits and social insurance was influenced by the recollection of the social tensions that had flared up in the aftermath of World War I. However, BIAs also strove to keep social programs financially sound and not too costly to employers. And the leitmotiv that state solutions should not encroach on existing private plans as well as guarantee managerial prerogatives remained an overarching objective.

In the somber international context of the late 1930s, the duration of army service was extended, and the Confederation began to prepare contingency plans to face the eventuality of war. This situation fueled demands from political parties, trade unions and the army command for the Confederation to introduce a comprehensive system to compensate income loss during militia duties. Employers were all the more aware of the pressing need to manage flows between army service and private employment that many among themselves served as militia officers. They also recognized that such a social policy scheme would contribute to ensure loyalty within the rank and file as well as improve industrial and social relations during an upcoming conflict (Eichenberger, 2016; Leimgruber, 2018). Employers acted rapidly and preemptively in this domain in order to prevent less advantageous solutions in both financial and organizational terms. As Otto Steinmann, secretary of the Arbeitgeberverband and key architect of the EO, underscored in December 1938:

If we do not act rapidly, trade unions will certainly launch a popular initiative [in favour of soldiers' income compensation]. We will have no influence on the content of this project and it will be exceedingly difficult to oppose it. Therefore, we have to act boldly.

(Quoted in Leimgruber, 2009, p. 82)

Acting boldly meant here for employers to set up proactively a new social policy. Steinmann reiterated this position at the war outbreak:

Employers have the choice between a solution in which the state would exercise an extensive control and one that, although mandatory, may grant employers the responsibility to implement the system.

(Arbeitgeberverband, 1939, p. 113) 
In the fall of 1939, a new and innovative federal social policy, the EO, was implemented through BIAs structures. A 4 percent payroll contribution (paid jointly by employers and employees) was levied on all male and female wage workers in order to finance benefits linked to soldiers' family and marital situation (fathers received more benefits than either childless married men or unmarried soldiers). New sector-wide equalization funds (Ausgleichskassen, AKs) managed by BIAs collected these contributions and paid benefits. Despite divergences among employers - which found their origins either in the composition of their workforce (i.e., sectors and firms employing many women were more reluctant to contribute to the EO) or in the extent of army mobilization among their employees - the Arbeitgeberverband prevailed because nascent AKs proved to be effective tools to force dissenting employers to toe the line (Eichenberger, 2016, pp. 199-252). If cantonal AKs were also set up to cover wage workers outside of sector-wide AKs, the latter dominated the system, a situation that still prevails in 2019.

The success of this preemptive action might seem surprising at first. However it can be explained by the fact that BIAs cohesiveness contrasted with crippling internal divisions among trade unions at war outbreak (the main industrial union, the Metalworkers' Union, was thus defiant towards both the Trade Union Federation and the Socialist Party) as well as the weaker integration of the left and labor in the war economy apparatus. In other words, the setting up of AKs, at first sight a purely administrative institution, represented a significant step in strengthening both business involvement in social provision and BIAs' internal discipline. In addition to the late 1930s disciplining of BIAs mentioned in the preceding section, mandatory affiliation of individual employers to BIAs-controlled AKs further narrowed the space for open dissent within the business community.

BIAs' prominent role in social policy was buttressed by a second surge of corporate welfare schemes. Spurred by new tax exemptions as well as wage freezes to limit inflation, hundreds of firm-based schemes were established from 1941 onwards (see Figure 4.2). Life insurers offered group pension plans to many small and medium-sized enterprises, corporate health schemes were extended and numerous firms offered cost-of-living supplements to smooth price inflation. In parallel to the EO, BIAs also favored the creation of hundreds of family allowances AKs, a dynamic that would make employers key providers of family benefits for decades to come. The impact of this second wartime surge is visible in the impressive extent of corporate welfare schemes recorded for the year 1950 in Table 4.1. Both the BIAs preemptive strike in the EO domain and the corporate welfare surge further strengthened business bargaining power during the following debates about postwar social policy, and in particular the shape of oldage pensions (AHV).

\subsubsection{BIAs and the shaping of the postwar welfare state, 1944-1948}

As we have seen in the preceding section, the AHV had suffered a crippling defeat in 1931. The project resurfaced around 1942-1943 when several 
popular initiatives as well as parliamentary projects attempted to capitalize on the EO success and put again the issue of a "secure old age" (the name of an eponymous popular initiative) at the top of the political agenda. The FDP Federal Councilor in charge of the dossier, Walther Stampfli, had worked as social secretary in the Von Roll foundry and had represented the firm in the committee of the pension lobby SVUSAI during the interwar. Elected in the summer of 1940 in the federal executive branch, Stampfli was a reliable member of the FDP "business wing" (Wirtschaftsfreisinn). He was indeed the genuine "economic general" of World War II on both the external (diplomatic relations with the Axis and Allied) and internal (AHV and the war economy) fronts (Hafner, 1986). Because of his involvement within the pension lobby (renamed SVPP in 1942), Stampfli was at first very lukewarm towards any AHV project. However, he acknowledged in 1943 - at the time when the British Beveridge Report caused a sensation in Switzerland (Monachon, 2002) - that something had to be done for political reasons in order to smooth the incoming transition from war to peace. Under Stampfli's guidance, a dynamic both replicating and extending the logic that had made the 1939-1940 social policy breakthrough possible, EO financing and organization structures (PAYGO payroll levies and AKs) served as guidelines and blueprints for the AHV (Leimgruber, 2008; Eichenberger, 2016). Using payroll contributions avoided the need to raise new taxes to finance social insurance. With existing AKs being tasked to monitor contributions and benefits flows for federal old-age pensions, BIAs guaranteed themselves a strong position in the management of the future federal pension system. Benefits for all persons over 65 years old were capped at a very low level (around 10 percent of pre-retirement wages) so as to avoid any competition against existing pension plans.

Walther Stampfli himself was keen on protecting private provision. In a sense, Stampfli's AHV strategy mirrored the "supplemental approach" identified by scholars to describe US business conditional acceptance of Social Security (Jacoby, 1993, p. 543; Klein, 2003). As in the United States, the Swiss basic state pension would serve as a stepping stone for private welfare schemes. In 1944, an insurance journal thus argued that a "modest" state pension would favor the development of private insurance:

We do not believe that the introduction of old age insurance will be detrimental to [insurance] companies. On the contrary, if companies act shrewdly, state insurance will serve as a propaganda device for them, as it will give to the whole nation a feel for insurance. Knowing that they will receive a modest pension, people will be keen to supplement it by contracting a supplementary insurance that companies will develop especially for this purpose.

(Quoted in Leimgruber, 2008, p. 168)

Just as it had been the case in 1900 and in 1931, dissent, misgivings as well as some outright opposition towards social insurance could be heard among employers' 
ranks. However, in contrast to these previous episodes, dissent did not flare up in the open. Business stayed outside of the political campaign for the AHV and endeavored to restrain internal dissent. For example, the Vorort and the Arbeitgeberverband refused to finance the 1947 referendum against the AHV, which had to rely on the support of textile industrialists and private bankers.

If old-age pensions had been a long-time demand of the political left and were supported by most trade unions (in particular in the building trades and among civil servants), the left and labor had in definitive little say in the framing of the AHV. Socialist demands that the AHV should be financed through wealth or inheritance taxes found no parliamentary majority, and trade unions were left out in the implementation of benefits. Furthermore, the leadership of the largest trade union, the metalworkers' union (SMUV), was reluctant towards the AHV and would have preferred either union-based schemes or even joint provision with employers. Together with increasing dedication to collective bargaining and support for occupational provision, the SMUV found itself in - a concept used for similarly attuned US trade unions - an "institutional straight-jacket" (Gottschalk, 2000, p. 2; Leimgruber, 2008, pp. 169-173) that led it to support employers' preferences, while having limited influence over policy content.

To sum up, the wartime foundation of the EO and AHV constituted a double breakthrough and both programs had a decisive and lasting impact on Swiss social policy development. At the same time, far from dislodging employers from social policy, both episodes contributed to entrench business influence at the core of the welfare state (through business led equalization funds) as well as in supplementary social provision (through corporate pension plans and family allowances funds).

\subsection{Business and social security from growth to consolidation, 1948-1994}

The second half of the 20th century witnessed the consolidation of the hybrid nature of the Swiss welfare state. At first sight, controversies over social policy seemed to recede in the background. Whereas referenda had much contributed to slow down social policy development until the 1940s, the postwar decades witnessed the increasing, and successful, use of popular initiatives demanding either benefits expansion or new social programs. During private meetings, employers' representatives acknowledged that this shift in the use of direct democracy confirmed that support for the extension of social insurance was strong across political parties and public opinion. Consequently, BIAs should avoid leading outspoken campaigns against social policy expansion. Instead, their attention should focus - in the words of a Vorort secretary in 1963 - towards "practical action" and they should strive to "stay in the shadows" (quoted in Eichenberger, 2016, p. 416). This posture was facilitated by BIAs participation in the management of social insurance and their integration in expert commissions that remained sheltered from parliamentary debates and direct democracy. By striving to cool down the "politicization of social policy" (Eichenberger, 2016) BIAs favored, to quote Pepper Culpepper (2011) seminal study, "quiet politics". Yet, 
by the end of the 1960s, the steady expansion in both public and private social provision progressively unraveled this seeming consensus and heated controversies on the frontiers of the welfare state resurfaced.

In this section, we deal with these various issues in two steps. In a first section, we underscore how business made sure to keep in check the institutional design of disability insurance, introduced in 1960, as well as strove to maintain the division of tasks between the AHV and occupational pensions. This period witnessed a moderate rise of social spending (from 6 percent of GDP in 1945 to around 8 percent in 1972). ${ }^{2}$ The second section, which runs from 1974 to 1994, encompassed the changes brought by the economic crisis to unemployment insurance, a key issue for employers, as well as repeated - but finally inconclusive - attempts to reform health insurance, a domain in which business had the least traction. This period witnessed a doubling of overall social expenditures (from around 10 percent of GDP in 1975 to 20 percent in 1995). We wind up our long-term survey by the mid-1990s, when all major social insurance branches had been introduced. In both sections, overall business aims focused on limiting the expansion of state benefits, avoiding the cross-subsidization of existing social programs, and safeguarding private solutions.

\subsubsection{Avoiding "overreaching solidarity" and monitoring the boundaries of the welfare state, 1948-1974}

If the postwar decades witnessed a gradual expansion of social spending, this trend was not linear. Indeed, spending for social insurance actually decreased from 1944 to 1948 due to the "de-mobilization" of EO benefits, and it was only around 1960 that the high mark from 1944 (around 6 percent of GDP) was overtaken. In the context of economic growth and full employment, the introduction of disability insurance (Invalidenversicherung, IV) - whose principle had been accepted in 1925 but since then sidelined and delayed by the focus on the AHV - was a direct response to two popular initiatives launched around 1955 by the Socialist Party and the small Labor Party (Communist). This use of direct democracy to spur goverment action, first visible in the 1941 "secure old age" initiative, would become a mainstay of the postwar decades. In the absence of war-wounded and victims, disability insurance was above all a labor market issue and was rapidly waived through parliament. According to employers' demands, the 1960 IV favored "labor force integration over benefits" (Germann, 2008) and contributed, albeit in a limited way, to alleviate manpower shortages. Moreover, the IV was integrated into the AHV financial (PAYGO payroll contributions) and institutional (employer-controlled AKs) framework (Fracheboud, 2015). In this context, BIAs favored payroll contributions over new state taxes, and strove to limit both "overreaching solidarity" (Überspitzung des Solidaritätsgedankens) and unwelcome income redistribution (Arbeitgeberverband 1956, p. 9). A key preocupation was also to prevent financial transfers between existing social insurance programs. Similar conceptions facilitated the uncontroversial 1958 revision of EO allowances, which constituted the social facet of Swiss Cold War 
military mobilization (Leimgruber, 2018; Longchamp, 2014). Finally, the AHV/ IV/EO triad was implemented through employers' AKs, which consolidated business involvement in postwar social security. This favorable position also enabled business to ward off demands from Catholic politicians for improved family policies. Categorically opposed to a federal law on family allowances, employers favored instead the piece-meal extension of family support in the context of decentralized collective labor agreements (CLAs), with benefits remaining under the supervision of employer-led family allowances programs (see Table 4.1). In contrast to the EO/IV reforms as well as family policy, old-age provision proved much more controversial.

From 1949 to 1973, the federal government enacted no less than eight AHV revisions, mainly focusing on incremental benefits expansion. This reform pace notably accelerated from 1959 onwards with the nomination of the first socialdemocratic Federal Councilor, Hans-Peter Tschudi, at the head of the Department of the Interior in charge with social security. These revisions must be understood in the context of the meagerness of initial AHV benefits, which amounted to a 10-20 percent wage replacement rate until the eighth AHV revision of 1973-1975. Even after that revision, the last expansive one to date, AHV benefits would amount to around 35 percent of an average wage (Lengwiler, 2003, pp. 45-46). But the "Tschudi pace", as well as foreign examples, such as the 1957 introduction of benefits indexation in Germany, unsettled employers and proponents of private social provision. None of the proposed AHV revisions was seriously opposed in Parliament. As BIAs were reticent to launch referenda campaigns, other ways had to be found to curb this expansionary trend.

The introduction of means-tested AHV supplements (AHV Ergänzungsleistungen) instead of across-the-board benefits increases was thus welcomed in 1964 by BIAs as a useful counter-measure. However, it became rapidly clear that bolder measures were necessary to contain future AHV expansions (Leimgruber, 2008). Life insurance companies took the lead in this strategy in order to convince BIAs and bourgeois political parties of the necessity to reaffirm the division of tasks between the AHV and occupational pension plans. This project gained in urgency by the end of the 1960s when competing leftwing "people's pensions" (Volkspensionen) popular initiatives envisioning a significant extension of paygo benefits were launched by the Socialist and Labor parties. Considered as direct challenges against funded provision organized by firms and insurers, the Volkspensionen were countered with the "three pillar" doctrine. First laid out by insurers as a propaganda tool to promote the division of tasks between the AHV (first), occupational (second) and individual (third) "pillars" of old-age provision, the doctrine designated mandatory affiliation to existing pension plans as an alternative to PAYGO extension. Mandatory affiliation was favored by most industrial employers - which were already well-covered by pension plans - but came at a cost for small business owners who had invested much less in this domain. Because of their interest in developing the market for group plans, life insurers were keen proponents of mandatory affiliation. The generalization of the "second pillar" was also welcomed by industrial trade unions, which considered 
it as a potential opportunity to gain more say in pension management and the investment of their funded reserves. When the three-pillar doctrine soundly defeated the Volkspensionen in a December 1972 vote, these different, and potentially divergent, conceptions still had to be sorted out and, as we will see below, the shaping of the federal law on mandatory occupational provision would only come into force in 1985. Combined together, the eighth AHV revision of 1972, which introduced a 40 percent expansion of benefits costs, and the promise to expand occupational provision accounted for most of the growth of social insurance spending during the 1970s and 1980s (Leimgruber, 2008).

\subsubsection{Towards cost containment and marketization: BIAs and the increasingly "mature" welfare state, 1974-1990s}

The mid-1970s marked an ambivalent turning point for social policy development. On the one hand, benefits kept on increasing and the coverage rate of social insurance programs became more encompassing (see Figure 4.1). On the other hand, some business circles, notably small and medium employers, started to contest social policy expansion in an increasingly confrontational manner while the idea of a "crisis" of the welfare state gained traction. By the 1990s, the Swiss welfare state was both typical and at odds with developments in neighboring countries. In terms of social expenditures, the country was not anymore in a "laggard" position but was catching up with the western European average (Moser, 2008). However, this normalization and convergence was realized in large part by the integration of private social spending, notably occupational old-age provision, in comparative statistics. Slowing economic growth also pushed up the social expenditure rate as benefits outlays remained stable. This evolution was finally the consequence of a change in social policy preferences among trade unions, which increasingly supported the extension of state solutions over both union-run welfare schemes and social benefits negotiated in the context of CLAs (Trampusch, 2010).

Unemployment had remained very low in Switzerland until the 1970s and unemployment plans, most of which were still controlled and managed by trade unions, covered then only around a quarter of all wage workers. When lay-offs surged during the 1974-1975 recession, the financial organization of unemployment insurance - which had been partially centralized during World War II but still encompassed no contributions from employers - almost imploded. As Tabin and Togni (2013, pp. 165-168) have underscored, this situation gave the political impetus for the foundation of comprehensive social insurance in this domain. As an Arbeitgeberverband secretary argued in 1975, BIAs bargained their support for the introduction of a joint employer-employee payroll contributions to pay for the new scheme:

In our circles, employers' contributions have until now met few favourable opinions, but it is politically unavoidable, because unemployment 
insurance is the way to avoid measures - such as those currently been implemented in France - increasing protections against redundancies.

(Quoted in Tabin \& Togni, 2013, pp. 165-166)

In other words, the secretary insisted that compensating the social consequences of Swiss flexible labor market regulations was the "price" employers had to pay to safeguard their "freedom of action". The Arbeitgeberverband also successfully intervened to limit the redistributive aspects of the insurance, notably in terms of the duration of benefits, and refused that unemployment insurance, which was belatedly introduced in 1982, could be used to ease industrial restructuring. These measures strongly limited the autonomy of trade unions in the management of their unemployment funds.

As mentioned above, the implementation of the second pension pillar also dragged on during the 1970s. After the decisive vote of 1972, bourgeois parties and BIAs not only conditioned their acceptance of mandatory affiliation to an end to the expansion of AHV benefits, they also fought step by step and successfully - in sharp contrast to the limitation of the automomy of trade union's unemployment funds mentioned above - to safeguard the autonomy of existing pension plans. After a decade of negotiations, the federal law on occupational provision (Berufliche Vorsorgegesetz, BVG) accepted in 1982 (and implemented in 1985) offered only a very loose framework. Existing pension plans could maintain their financing and benefits structure, the extension of coverage (which rose from one-half to four-fifth of the non-farm workforce between 1978 and 1987) was delegated to private providers, especially life insurers, and the law guaranteed managerial prerogatives in pension plans. As the focus of old-age pension development shifted from the AHV to occupational provision, a Vorort secretary admitted in 1983 that the BVG represented "an intervention of the state in a domain that used to be left unregulated." Yet, he continued,

it will hopefully fill a genuine social policy gap and serve as a barrier against any expansion of the AHV towards Volkspensionen. This is what motivated [employers] to accept the principle of mandatory affiliation

(Vorort 1983, p. 28)

Small- and medium-sized enterprises (SMEs) and their BIA, the Gewerbeverband, were more critical towards social policy. For the first time since World War II, in 1977, the Gewerbeverband launched a referendum against an AHV revision, arguing that benefits had to be reduced instead of being expanded (Ruoss, 2015). Although the Gewerbeverband lost the popular vote, this referendum signaled the return of open dissensions among BIAs on social policy reforms. Opposition came in particular from SMEs and domestic-oriented sectors. Traditionally less proactive in the domain of firm-based social provision, these employers were reluctant towards both state and private social insurance providers.

From the mid-1960s onwards, the issue of health insurance was constantly on the political agenda. Ongoing changes such as the professionalization of health care 
and the extension of hospital care contributed to increase costs. But despite repeated attempts, almost all efforts to reform health insurance failed to change its core parameters (Kocher, 1972). Health insurance was also the domain in which employers had the least traction. If some industrial firms still operated their own sickness funds, most employers were only loosely connected to existing health plans, whose diversity ranged from very small local structures to large mutuals active at the national level. But even these key providers had little contacts with BIAs and functioned outside of the commercial insurance sector. Employer organizations strove above all to avoid any obligation to pay for either medical care or wage continuation (Tagesgeld) during sickness. Wage continuation was mostly linked to CLAs, which stipulated employers' contributions to funds compensating salary losses during sickness periods (Derron, 1958, p. 60).

At the end of the 1960s, two popular initiatives - the first one launched by the Socialist party and the second by health plans - proposed wide-ranging reforms. In the policy process, employers showed readiness to compromise, for example, to use payroll levies to fund health care in order to avoid financing through general taxation or to implement wage continuation benefits as long as they remained subordinated trough CLAs. At the same time, BIAs rejected both the principle of mandatory affiliation to health plans as well as maternity benefits. In the end, both initiatives as well as the government counter-project failed to garner enough popular support and the whole reform process ended in stalemate.

While reform attempts stalled, health providers underwent profound changes. In addition to the structural changes in the health sector mentioned above, the Confederation halved its direct subsidies to sickness funds. These factors accelerated a precipitous reduction of existing providers, as hundreds of small mutuals merged or were absorbed by larger providers operating according to commercial principles (see Table 4.1). This development was in line with the ideological preferences expressed by employers in terms of individual responsibility and competition between providers (Streckeisen, 2017; Arbeitgeberverband, 1988). However, this process loosened further the already weak institutional links between sickness funds and industrial relations. Protracted debates on health insurance, focusing on cost containment and harmonization of coverage continued unabated during the 1980s and 1990s, culminating in 1996 in a federal law consolidating universal health coverage and regulating competition between providers. By this time, trade unions and firm-based health plans had disappeared, and BIAs traction on the policy process was limited.

\subsection{Findings and discussion}

Our analysis of the Swiss case underscores that social policy was conceived and implemented with active participation from business interests and not against them. Employers often acted in order to preempt social policy initiatives. They fought to limit the scope of state regulation and participated in the implementation 
of social policies. BIAs gave their support to social legislation when state control over these programs could be kept to a minimum and when new programs would not challenge pre-existing private providers. Under these conditions, BIAs were also willing to support solutions that promoted labor market stability and eased the labor supply. As employers often underscored themselves (Hug, 1983, p. 121), financial issues were crucial. The financing solutions favored could differ quite significantly from one case to the other, depending on the alternatives discussed. More redistributive solutions were opposed, individual contributions were favored over payroll contributions, and tax-based financing of social programs were to be avoided as much as possible. A more in depth investigation of social insurance financing, a still neglected topic, would bring a better understanding of employers' preferences and options in this domain. Besides their political advantage, employers and insurers also benefited from the multifaceted and multi-level involvement of individual firms and sectoral BIAs in social provision (see Table 4.1). This granted BIAs the opportunity not only to intervene at multiple points in the policy making process but also to control the implementation of social provision, which leveraged their influence. Individual firms used pension plans and health funds for workforce management as well as to benefit from tax expenditures; sectoral BIAs used AKs to keep the state at arms' length and counter trade unions alternatives; and peak BIAs enjoyed direct access to Federal Councilors and to the policy process. They also made sure that the different options decided at the firm and/or branch levels did not endanger the overall coherence of business positions within the national political system. This "constituted field of interest" (Rodgers, 1998), in which employers were particularly strong, proved extremely resilient.

The diversity of employer-controlled social provision enabled economic sectors and firms to follow their own priorities in terms of labor market regulation and participated to shape employers' preferences for branch-wide and company-level CLAs. However, the extent to which CLAs included negotiated social benefits remains a blind spot of our research. A systematic historical study of these interactions would undoubtedly enrich our understanding of Swiss industrial relations (see, however, Emmenegger, 2014; Trampusch, 2007, 2010).

Employers' influence in social policy development differed significantly between the phase of foundation of core social insurance programs (i.e., from the 1890s until the 1940s), during which controversial issues were openly debated within BIAs, and a phase of monitoring and managing of the public-private mix (i.e., after World War II). During the foundation phase, major social policy programs were to a large extent implemented by the pro-business FDP party. To a point, the main bourgeois party envisioned social policy as a contribution to consolidating the national community. During the second period, most influence was channeled through "quiet politics" (Culpepper, 2011), based on employers' multi-level involvement in policy-making and their direct participation in social provision. By this date, BIAs succeeded in enforcing internal discipline vis-à-vis social policy 
controversies, which enabled them to avoid disruptive flare ups and gain significant leverage in policy debates.

Business preferences were not homogeneous, and did not always prevail, as they had to accommodate diverging political preferences. This chapter makes clear that differentiated perception of interests, ideological stance and influence of political context interacted to shape employers' stance towards social policy. In the chapter, we do not find evidences of employers initiating public social programs. However, key bourgeois politicians as well as civil servants - often with a background in the industrial or insurance sector - shaped social insurance programs so as to make them as business-friendly as possible (on this argument in other contexts, see Swenson, 2002). In this sense, revolving doors between the state, business, BIAs and insurance companies played at full.

\section{Primary sources}

\section{Historical archives of the Arbeitgeberverband, Zurich}

Arbeitgeberverband (1931a), Ausserordentlichen Delegierten-Versammlung, 20 November 1931.

Arbeitgeberverband (1931b), Ausschuss, 29 October 1931.

Arbeitgeberverband (1939), Ausschuss, 26 September 1939.

Arbeitgeberverband (1956), Geschäftsführer-Konferenz, 8 May 1956.

Arbeitgeberverband (1988), "Positionspapier zur Krankenversicherung," in Vorstand, 14 September 1988, pp. 24-26.

\section{Historical archives of the Vorort, Archiv für Zeitgeschichte, Zurich}

Vorort 1983, Protokoll des Vororts, 29 August 1983, file IB Vorort-Archiv, 1.5.3.

\section{Notes}

1 In this chapter, we mostly focus on insurance-based social protection measures alleviating risks such as old age, invalidity, unemployment, accident and illness that constitute the core of social security systems in industrialized and wage-based societies. For a useful definition, see <www.issa.int>, "Understanding Social Security". We would like to thank Peter Streckeisen and Florian Müller for their comments on an early version of this chapter.

2 Expenditures for social insurance programs, 1925-2010<www.historyofsocialsecur ity.ch/fileadmin/redaktion/Zahlen/G2.jpg>.

\section{References}

Bonoli, G., \& Häusermann, S. (2011). Swiss welfare reforms in a comparative perspective: between retrenchment and activation. In C. Trampusch \& A. Mach (Eds.), Switzerland in Europe, Continuity and Change in the Swiss Political Economy (pp. 205-223). London: Routledge. 
Culpepper, P. D. (2011). Quiet Politics and Business Power, Corporate Control in Europe and Japan. New York: Cambridge University Press.

Degen, B. (2012). Arbeit und Kapital. In P. Halbeisen, M. Müller, \& B. Veyrassat (Eds.), Wirtschaftsgeschichte der Schweiz im 20. Jahrhundert (pp. 873-922). Basel: Schwabe.

Derron, L. (1958). Der Gedanke der sozialen Sicherheit. In Z. S. Arbeitgeber-Organisationen (Ed.), Arbeitgeberpolitik gestern und heute. Festschrift zum fünfzigjährigen Bestehen des Zentralverbandes schweizerischer Arbeitgeber-Organisationen, 1908-1958. (pp. 31-50). Zurich: Chronos.

Eichenberger, P. (2016). Mainmise sur l'Etat social. Mobilisation patronale et caisses de compensation en Suisse (1908-1960). Neuchâtel: Alphil - Presses Universitaires Suisses.

Eichenberger, P. (2018). Les organisations patronales et la Grève générale de 1918. Traverse - Zeitschrift für Geschichte, 25(2), 129-149.

Eichenberger, P., \& Mach, A. (2011). Organized capital and coordinated market economy: Swiss business interest associations between socio-economic regulation and political influence. In C. Trampusch \& A. Mach (Eds.), Switzerland in Europe: Continuity and Change in the Swiss Political Economy (pp. 63-81). London: Routledge.

Emmenegger, P. (2014). The Power to Dismiss. Trade Unions and the Regulation of Job Security in Western Europe. Oxford: Oxford University Press.

Fleischmann, R. (2016). Eine typisch schweizerische Lösung. Die Geschichte des Schweizerischen Betriebskrankenkassenverbands ( $S B K V$ ). BA Thesis. University of Zurich.

Fracheboud, V. (2015). L'introduction de l'assurance invalidité en Suisse (1944-1960). Tensions au coeur de l'État social. Lausanne: Antipodes.

Germann, U. (2008). Eingliederung vor Rente. Behindertenpolitische Weichenstellungen und die Einführung der schweizerischen Invalidenversicherung. Schweizerische Zeitschrift für Geschichte, 58(2), 178-197.

Gottschalk, M. (2000). The Shadow Welfare State: Labor, Business, and the Politics of Health Care in the United States. Ithaca, NY: Cornell University Press.

Hafner, G. (1986). Bundesrat Walther Stampfi: Leiter der Kriegswirtschaft im Zweiten Weltkrieg. Bundesrätlicher Vater der AHV. Olten: Dietschi.

Häusermann, S. (2010). The Politics of Welfare State Reform in Continental Europe. Modernization in Hard Times. Cambridge: Cambridge University Press.

Hobsbawm, E. (2012). The Age of Extremes: 1914-1989. London: Abacus.

Hug, K. (1983). Aspekte einer künftige Sozialversicherungspolitik. In Z. S. ArbeitgeberOrganisationen (Ed.), Profile der Arbeitgeberpolitik. 75 Jahre Zentralverband schweizerischer Arbeitgeber-Organisationen 1908-1983 (pp. 102-122). Zurich: Chronos.

Humair, C. (2004). Développement économique et Etat central (1815-1914): un siècle de politique douanière suisse au service des élites. Bern: Peter Lang.

Jacoby, S. M. (1993). Employers and the welfare State: The role of Marion B. Folsom. The Journal of American History, 80(2), 525-556.

Jost, H. U. (1999). Le salaire des neutres: Suisse 1939-1948. Paris: Denoël.

Katzenstein, P. (1980). Capitalism in one country? Switzerland in the international economy. International Organization, 34(4), 507-540.

Katzenstein, P. (1984). Corporatism and Change: Austria, Switzerland and the Politics of Industry. Ithaca, NY: Cornell University Press.

Klein, J. (2003). For All These Rights: Business, Labor and the Shaping of America's Public-Private Welfare State. Princeton, NJ: Princeton University press.

Knüsel, R., \& Zurita, F. (1979). Assurances sociales: une sécurité pour qui? La Loi Forrer et les origines de l'Etat social en Suisse. Lausanne: Mémoires et documents de l'Institut de science politique. 
Kocher, G. (1972). Verbandseinfluss auf die Gesetzgebung: Aerzteverbindung, Krankenkassenverbände und die Teilrevision 1964 des Kranken- und Unfallversicherungsgesetzes. Bern: Francke.

Leimgruber, M. (2008). Solidarity Without the State? Business and the Shaping of the Swiss Welfare State, 1890-2000. Cambridge: Cambridge University Press.

Leimgruber, M. (2009). Schutz für Soldaten, nicht für Mütter. Lohnausfallentschädigung für Dienstleistende. In M. Leimgruber \& M. Lengwiler (Eds.), Umbruch an der "inneren Front”: Krieg und Sozialpolitik in der Schweiz, 1938-1948 (pp. 75-99). Zurich: Chronos.

Leimgruber, M. (2011) Syndicats et retraites en Suisse au XXe siècle: du rêve mutualiste à la défense des assurances sociales. In Cahier de l'AEHMO. Syndicats et politique sociale, 93-110.

Leimgruber, M. (2018). War and social policy development in Switzerland, 1870-1990. In H. Obinger, K. Petersen, \& P. Starke (Eds.), Warfare and Welfare: Military Conflict and Welfare State Development in Western Countries. Oxford: Oxford University Press. 364-92.

Lengwiler, M. (2003). Das Drei-Säulen-Konzept und seine Grenzen: private und berufliche Alterversorge in der Schweiz im 20. Jahrhundert. Zeitschrift für Unternnehmensgeschichte, 48(1), 29-47.

Lengwiler, M. (2006). Risikopolitik im Sozialstaat: die schweizerische Unfallversicherung, 1870-1970. Köln: Böhlau.

Lengwiler, M. (2007). Transfer mit Grenzen: das "Modell Deutschland" in der schweizerischen Sozialstaatsgeschichte (1880-1950). Itinera. Deutsche und Deutschland aus Schweizer Perspektiven, 47-66.

Lengwiler, M. (2009). Das verpasste Jahrzehnt: Krankenversicherung und Gesundheitspolitik in der Schweiz, 1938-1949. In M. Leimgruber \& M. Lengwiler (Eds.), Umbruch an der "inneren Front": Krieg und Sozialpolitik in der Schweiz, 1938-1948 (pp. 165-183). Zurich: Chronos.

Longchamp, O. (2014). La politique financière fédérale 1945-1958. Lausanne: Antipodes.

Mach, A., \& Oesch, D. (2003). Collective Bargaining Between Decentralization and Stability: A Sectoral Model Explaining the Swiss Experience During the 1990s. Industrielle Beziehungen, 10(1), 160-182.

Mach, A., David, T., Ginalski, S., \& Bühlman, F. (2016). Les élites économiques suisses au XXe siècle. Neuchâtel: Alphil.

Maier, C. S. (1988). Recasting Bourgeois Europe. Stabilization in France, Germany, and Italy in the Decade after World War I (1975 ed.). Princeton, NJ: Princeton University Press.

Monachon, J.-J. (2002). Le plan Beveridge et les débats sur la sécutié sociale en Suisse entre 1942 et 1945. In H.-J. Gilomen, S. Guex, \& B. Studer (Eds.), Von der Barmherzigkeit zur Sozialversicherung - De l'assistance à l'assurance socialeUmbrüche und Kontinuität vom Spätmittelalter bis zum 20. Jahrhundert - Ruptures et continuités du Moyen Age au XXe siècle (pp. 321-329). Zurich: Chronos.

Moser, J. (2008). Der schweizerische Wohlfahrtsstaat. Zum Ausbau des sozialen Sicherungssystems 1975-2005. Frankfurt: Campus.

Moses, J. (2015). Social policy, welfare, and social identities (1900-1950). In N. Doumanis (Ed.), The Oxford Handbook of Europe 1914-1945. Oxford: Oxford University Press, 323-42.

Muheim, D. (2000). Mutualisme et assurance maladie (1893-1912). Une adaptation ambigue. Traverse, 2, 79-93.

Müller, P. (2010). La Suisse en crise (1929-1936). Les politiques monétaire, financière, économique et sociale de la Confédération helvétique. Lausanne: Antipodes. 
Obinger, H. (1998). Federalism, direct democracy, and welfare state development in Switzerland. Journal of Public Policy, 18(3), 241-263.

Obinger, H., Armingeon, K., Bonoli, G., \& Bertozzi, F. (2005). Switzerland: The marriage of direct democracy and federalism. In H. Obinger, S. Leibfried, \& F. G. Castles (Eds.), Federalism and the Welfare State: New World and European Experiences (pp. 263-306). Cambridge: Cambridge University Press.

Oesch, D. (2011). Swiss trade unions and industrial relations after 1990: A history of decline and renewal. In C. Trampusch \& A. Mach (Eds.), Switzerland in Europe. Continuity and Change in the Swiss Political Economy (pp. 82-102). London: Routledge.

Oude Nijhuis, D. (2013). Labor Divided in the Postwar European Welfare State: the Netherlands and the United Kingdom. Cambridge: Cambridge University Press.

Richard, E., \& Georg, A. (1911). Pourquoi nous demandons le referendum sur la loi fédérale concernant l'assurance en cas de maladie et d'accidents du 13 juin 1911. Zürcher Handelskammer.

Rodgers, D. (1998). Atlantic crossings: Social politics in a progressive age. Cambridge, MA: Harvard University Press.

Ruoss, M. (2015). Fürsprecherin des Alters. Geschichte der Stiftung Pro Senectute im entstehenden Schweizer Sozialstaat (1917-1967). Zuirch: Chronos.

Schmid, H. (1983). Wirtschaft, Staat und Macht. Die Politik der schweizerischen Exportindustrie im Zeichen von Staats- und Wirtschaftskrise. Zurich: Limmat.

Schumacher, B. (Ed.) (2010). Freiwillig verpflichtet. Gemeinnütziges Denken und Handeln in der Schweiz seit 1800. Zurich: NZZ Verlag.

Streckeisen, P. (2017). Von der Profession zum Markt. Forschungsbericht zur Ökonomiesierung des schweizerischen Gesundheitswesens. Working paper. EMH Schweizerischer Ärzteverlag.

Studer, B. (2012). Ökonomien der sozialen Sicherheit. In P. Halbeisen, M. Müller, \& B. Veyrassat (Eds.), Wirtschaftsgeschichte der Schweiz im 20. Jahrhundert (pp. 923-974). Basel: Schwabe Verlag.

Swenson, P. (2002). Capitalists Against Markets. The Making of Labor Markets and Welfare States in the United States and Sweden. Oxford: Oxford University press.

Tabin, J.-P., \& Togni, C. (2013). L'assurance chômage en Suisse. Lausanne: Antipodes.

Trampusch, C. (2007). Industrial relations as a source of solidarity in times of welfare state retrenchment. Journal of Social Policy, 36(2), 197-215.

Trampusch, C. (2010). The welfare state and trade unions in Switzerland: An historical reconstruction of the shift from a liberal to a post-liberal welfare regime. Journal of European Social Policy, 20(1), 58-73.

Trampusch, C., \& Mach, A. (2011). The Swiss political economy in comparative perspective. In C. Trampusch \& A. Mach (Eds.), Switzerland in Europe, Continuity and Change in the Swiss Political Economy (pp. 11-26). London: Routledge.

Veyrassat, B. (2012). Wirtschaft und Gesellschaft an der Wende zum 20. Jahrhundert. In P. Halbeisen, M. Müller, \& B. Veyrassat (Eds.), Wirtschaftsgeschichte der Schweiz im 20. Jahrhundert (pp. 33-81). Basel: Schwabe.

Wehrli, B. (1972). Le Vorort, mythe et réalité. Histoire de l'Union suisse du commerce et de l'industrie 1870-1970. Neuchâtel: La Baconnière.

Wirz, H. G. (1955). Die Personal-Wohlfahrtseinrichtungen der schweizerischen Privatwirtschaft: ihre Stellung im Steuerrecht und ihre Beaufsichtigung. Stäfa: Buchdruckerei Stäfa. 


\section{Appendix: Figures and Tables}

Table 4.1 The Swiss "Kassenwesen" and the Decentralized Organization of Social Policy, 1920-2010

\begin{tabular}{|c|c|c|c|c|c|}
\hline & 1920 & 1950 & 1980 & 2010 & Business/labour involvement \\
\hline $\begin{array}{l}\text { SUVA/ } \\
\text { Accident } \\
\text { insurance }\end{array}$ & 1 & 1 & 1 & $1 / 27$ & $\begin{array}{l}\text { SUVA tripartite structure } \\
\text { includes labor and business } \\
\text { Casualty insurers }\end{array}$ \\
\hline Health funds & $>900$ & 1150 & 550 & 80 & $\begin{array}{l}\text { (until 1980s) Trade union } \\
\text { mutuals and firm-based plans } \\
\text { Health insurers }{ }^{b}\end{array}$ \\
\hline Pension funds & $>300$ & 5200 & $\sim 10 ’ 000$ & $\sim 2000$ & $\begin{array}{l}\text { Firm-based plans } \\
\text { Group life insurance } \\
\text { Marginal labor involvement }\end{array}$ \\
\hline $\begin{array}{l}\text { Unemployment } \\
\text { funds }\end{array}$ & 60 & 190 & 140 & $38^{\mathrm{d}}$ & $\begin{array}{l}\text { Strong labor involvement } \\
\text { Sector-wide and regional } \\
\text { BIAs }\end{array}$ \\
\hline $\begin{array}{l}\text { EO/AHV/IV } \\
\text { equalization } \\
\text { funds } \\
\text { (employers/ } \\
\text { cantons) }\end{array}$ & 0 & $77 / 25$ & $76 / 26$ & $51 / 26$ & $\begin{array}{l}\text { Sector-wide and regional } \\
\text { BIAs } \\
\text { Limited labor involvement }\end{array}$ \\
\hline $\begin{array}{l}\text { Family } \\
\text { allowances } \\
\text { funds }\end{array}$ & $<10$ & $\sim 600$ & $\sim 800$ & $\sim 800$ & $\begin{array}{l}\text { Sector-wide and regional } \\
\text { BIAs } \\
\text { Limited labor involvement } \\
\text { (CLAs) }\end{array}$ \\
\hline
\end{tabular}

Note: This table indicates how many institutions were responsible for the implementation of various social policy risks as well as indicates the form(s) of business and labor involvement in this "institutional universe" (Kassenwesen). More details can be found in the different sections.

a After the 1918 foundation of the SUVA, casualty insurers could not offer industrial accident contracts. A 1984 reform re-opened the market.

${ }^{\mathrm{b}}$ By the late 1990s, large health insurance companies joined the Swiss Insurance Federation, thus leaving behind their mutualist origins.

${ }^{c}$ Besides a few hundred large firm-based plans, a handful of life insurance companies provided group coverage, which constituted the bulk of existing pension funds. Group plans represented $76 \%$ of existing pension funds in 1950 and around $35 \%$ at the turn of the millennium (Leimgruber, 2008, pp. 81, 290).

d In 2010, 38 "central offices" managed 155 unemployment funds. Data for 1920 and 1980 cover, respectively, 1924 and 1974.

Figure 4.1 displays the key development sequences for four social policy domains using two sets of indicators: Dates signal key foundational legislative moments as well as failed attempts (in italics) to introduce social insurance. Pie charts indicate the expansion of risk coverage. 


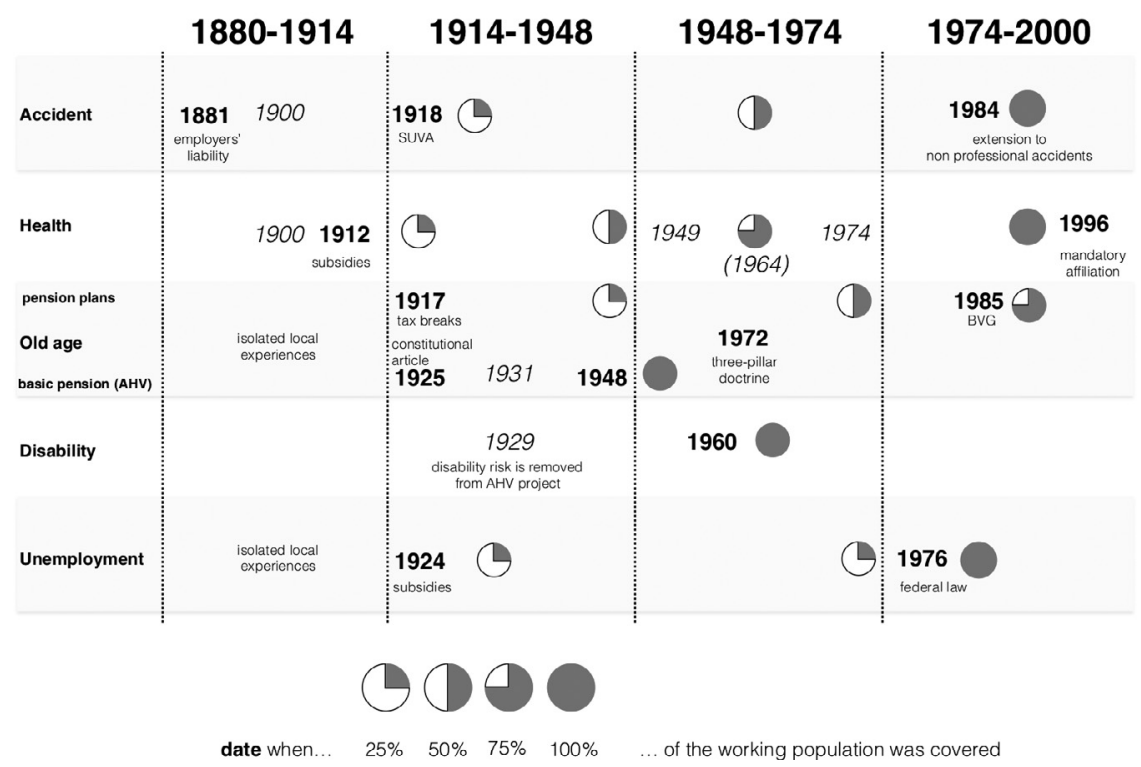

Figure 4.1 Overview of major social insurance reforms in Switzerland, 1880-2000 Source: Information compiled from various sources, authors' own creation.

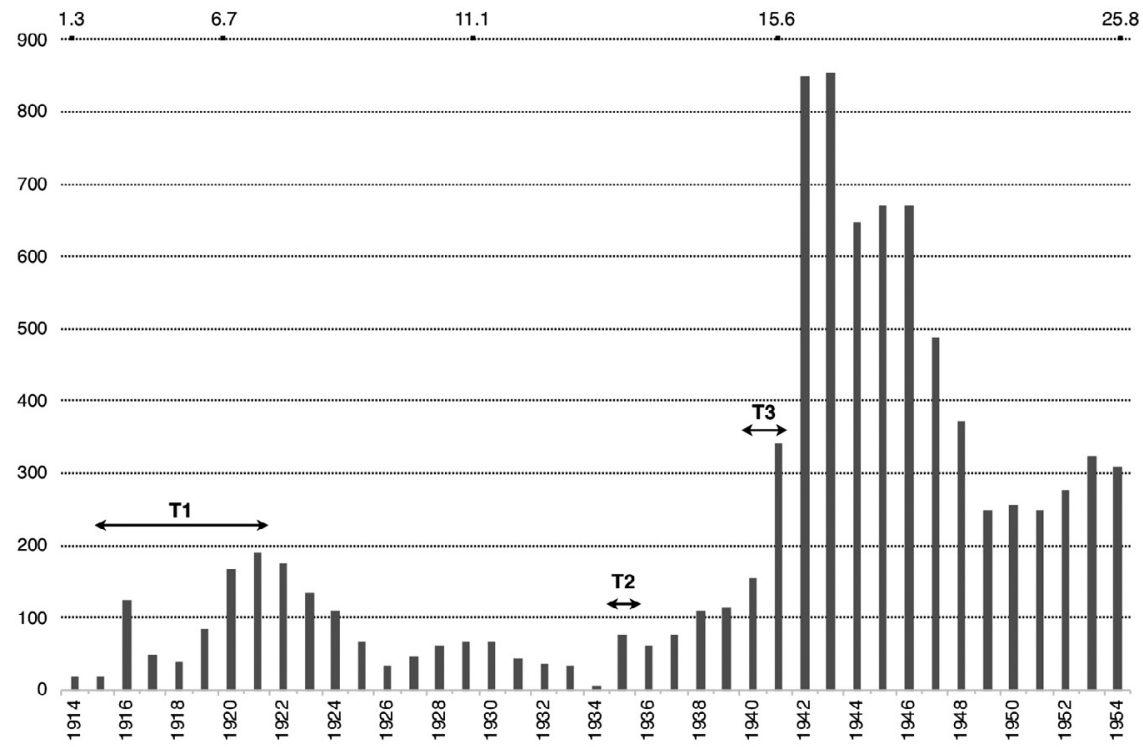

Overhead numbers = pension coverage in percent of the private workforce (see Leimgruber, 2008, p. 295) T2 -T3 = tax breaks for private welfare institutions (see below)

Figure 4.2 New welfare institutions in the Swiss private sector, 1914-1954

Source: Information compiled from Wirz, 1955, p. 2, as well as Leimgruber 2008, p. 66. 